\title{
$\boldsymbol{u}^{b}$
}

UNIVERSITĂT

BERN

\section{Institute of Information Systems}

University of Bern

Working Paper No. 242

\section{THE EVOLUTION OF CONTRACTUAL AND RELATIONAL GOVERNANCE IN IS OUTSOURCING}

\author{
Thomas Fischer* \\ Thomas Huber* \\ Jens Dibbern \\ Rudy Hirschheim
}

June 2012

The Working Papers of the Institute of Information Systems are intermediate results from current research projects and should initiate scientific discussion; criticism of the content is desired and welcome. All rights reserved.

Address: $\quad$ Engehaldenstrasse 8, CH-3012 Bern, Switzerland

E-Mail: $\quad$ thomas.fischer@iwi.unibe.ch

Address: $\quad$ Engehaldenstrasse 8, CH-3012 Bern, Switzerland

E-Mail: $\quad$ thomas.huber@iwi.unibe.ch

Address: $\quad$ Engehaldenstrasse 8, CH-3012 Bern, Switzerland

E-Mail:_ jens.dibbern@iwi.unibe.ch

Address: $\quad$ Louisiana State University, 3197 Patrick F. Taylor Hall, Baton Rouge, LA, 7080, USA

E-Mail: $\quad$ rudy@lsu.edu

* T. Fischer and T. Huber contributed equally to this work 


\title{
THE EVOLUTION OF CONTRACTUAL AND RELATIONAL GOVERNANCE IN IS OUTSOURCING
}

\begin{abstract}
This paper explores how and why contractual and relational governance evolve over time in information systems (IS) outsourcing projects. Governance is broken down into its foundation and action dimension resulting in four governance parameters: trust /norms and informal control representing relational governance; contract and formal control reflecting contractual governance. Drawing on the lenses of punctuated equilibrium and biological interaction, we examine both incremental and disruptive change along our four governance parameters. The findings from four longitudinal IS outsourcing projects suggest that incremental changes are driven by interactions between governance parameters. We found three basic patterns of interaction between governance parameters (mutualism, commensalism, competition) that explain incremental changes. In contrast, disruptive governance changes during revolutions are driven by stark contextual changes. However, interactions during equilibriums may lead to self-perpetuating dynamics that may detract governance from basic outsourcing objectives. Revolutions may break these self-perpetuating dynamics and redirect governance to basic objectives.
\end{abstract}

Keywords: Contractual Governance, Relational Governance, IS Outsourcing, Dynamic Perspective, Punctuated Equilibrium, Governance Interaction, Biological Interaction 


\section{INTRODUCTION}

The importance of contractual and relational governance for successful information systems (IS) outsourcing is now well recognized [1-4]. Typically they are used in combination in IS outsourcing projects in the form of a governance portfolio [c.f., 5, 6]. As an example, client and vendor contractually agree to follow formal processes (contractual governance) and additionally rely on trustbased spontaneous cooperation (relational governance) [7]. The composition of this portfolio in a particular IS outsourcing arrangement was found to be contingent upon the particular context as reflected by the characteristics of the outsourced task or the involved stakeholders [6].

The outsourcing context, however, is often subject to change over time, requiring the portfolio of governance mechanisms to be adapted accordingly. For example, Kirsch [8] found the portfolio of control mechanisms used in outsourcing projects to change from one project phase to another. Similar findings emerged from other studies that have taken a dynamic perspective on IS outsourcing governance [e.g., 9, 10]. These studies share a common focus on critical events or encounters that represent rare and disruptive contextual changes that are followed by major governance changes [11]. The focus on such event driven disruptive governance change is in stark contrast to research that holds that change unfolds in an incremental and continuous way [11, 12]. Moreover, such incremental governance changes may unfold in a rather subtle way through the social process of service delivery itself rather than being established by an authority at a single point of time [13]. For example, if the development of a software application is outsourced to an external vendor, the software requirements are rarely fixed at the outset; instead, the requirements often emerge after the actual development process has started and it is likely that new software functionalities may be added during all phases of a project. To govern such a constantly moving target might necessitate changing governance mechanisms regularly. To see if this is true, this study examines two specific research questions: How do IS outsourcing governance mechanisms change over time both incrementally and disruptively? And what are the drivers for such incremental as opposed to disruptive changes?

To establish a conceptual umbrella that captures both incremental and disruptive changes in IS outsourcing governance mechanisms, we draw on the punctuated equilibrium model [14] from evolutionary biology. This model explicitly distinguishes between long equilibrium phases of incremental changes characterized by competitive, evolutionary selection, and short and disruptive phases of revolutionary upheaval that are triggered by strong events. However, as the explanatory focus of punctuated equilibrium is mainly on the revolutionary phases, we complement the model with a second lens from evolutionary biology - that of biological interaction. This theory explicitly recognizes the fact that the evolution of one particular species may depend on the evolution of another species. More specifically, the theory postulates that incremental changes of species are the outcome of five different types of biological interaction- Mutual Beneficial; Commensalism; Antagonism; Competition and Amensalism [15, 16]. Using this notion, we argue that similar types of interactions may exist between different (species of) governance mechanisms and that these interactions drive incremental change.

To examine such interactions in detail, we first combine existing governance dimensions into a coherent framework consisting of four governance parameters: trust/norms; informal control; contract; and formal control. Two of these parameters - trust/norms and informal control - reflect the species of relational governance. The other two - contract and formal control - make up the species of contractual governance. We argue that interactions both within and between the species of contractual and relational governance breed incremental changes of governance. Phases of evolutionary interaction between governance mechanisms may then be punctuated by disruptive phases.

To uncover interaction patterns between governance mechanisms we analyzed four IS outsourcing projects of an international bank over approximately four years. For each of these projects we 
identified incremental governance changes along the four parameters of our framework and mapped them to the five types of biological interaction. For both phases of incremental and disruptive change we uncovered different drivers of change.

By opening the black box of evolutionary changes in phases of relative contextual stability, and contrasting them with those of contextual upheaval, our study provides new insights into how and why IS outsourcing governance changes. In fact, as shown in our results, revolutionary change is triggered by dramatic contextual changes. In contrast, incremental change of governance mechanisms is driven by interactions between and within contractual and relational governance. We identified three interaction patterns driving incremental governance change that together result in self-perpetuating (co-) evolutionary dynamics with refinement and differentiation of governance mechanisms as a result. However our results also show that phases of incremental and radical change are closely intertwined. This inter-connectedness causes a significant challenge for managers. Change driven by selfperpetuating dynamics may detract from the initial outsourcing objectives. Revolutions in contrast may not only lead to the need to adapt governance to the new situation, but also to reverse those governance actions and routines that emerged during the evolutionary phase.

Our study contributes to research and practice in three major ways. First, we build a process theory of IS outsourcing governance, which we identified as a major gap in the IS outsourcing literature [17, 18]. In doing so we provide for the first time a micro-view on the emergence, adaptation and exercise of IS outsourcing governance mechanisms. Second, we introduce and apply the new lens of biological interaction to explain incremental changes of IS outsourcing governance. We thereby contribute to both punctuated equilibrium and reference theories associated with governance (e.g. control theory). Third, we provide managers with meaningful guidance on how to deliberately take advantage of the benefits of self-perpetuating incremental change and context-driven revolutionary change.

The paper proceeds as follows: the next section describes the theoretical foundation of our study. Next, the research strategy and design are discussed. We then present our data analysis and findings. Lastly, we offer the implications of these findings for research and practice.

\section{THEORETICAL BACKGROUND}

\subsection{Four-Parameter Framework of Governance Change}

Since our primary objective is to explain how and why IS outsourcing governance mechanisms change over time, we follow a process-theoretic approach [19]. The first important step in this endeavor is to clarify the unit of change [20]. In our study, the unit of change refers to the particular contractual and relational governance mechanisms used in IS outsourcing arrangements. Prior research has conceptualized both contractual and relational governance quite differently.

Contractual governance has been defined in two major ways; first, as "the use of a formalized, legallybinding agreement or a contract to govern the interfirm partnership" [21, p. 898]. This definition highlights the use or exercise of formal control as defined in a contract. Second, the focus was on the contract highlighting its key characteristics (e.g., different types of service level agreements, complexity, level of detail) [22-24].

In a similar vein, two different ways of conceptualizing relational governance can be found. The first definition focuses on "the role of mutual trust, commitment, and relational capital" [21, p. 898] in forming the relationship between client and vendor. This perspective advocates social components especially trust and shared norms - as the way to shape economic exchanges [22, 25]. The second 
definition emphasizes social actions, such as "open communication, open sharing of information, (...) and cooperation" (Lacity et al. 2009, p. 137) as the building blocks of a relationship. Such actions are referred to as informal control [8].

It is interesting to note that in both contractual and relational governance, emphasis is either given to the actions taken to govern a relationship, i.e. the exercise of formal and informal control, or to the foundations of contractual and relational governance, i.e. trust / shared norms and contract. It is further important to recognize that the foundation and action dimension of contractual and relational governance are not independent of each other. In fact, in contractual governance, the exercise of formal control (action) is based on the contract (foundation), and in relational governance trust and social norms (foundations) it may be seen as the basis for informal control (action) [26] [7].

Since our object is to capture the changes in IS outsourcing governance as comprehensively as possible and to consider possible dependencies between its sub-dimensions, we propose a framework that divides contractual and relational governance along their action and foundation dimensions: Contract refers to the foundation of contractual governance, trust and relational norms refer to the foundation of relational governance, informal control refers to the action based on trust and shared norms, and formal control refers to the actions derived from the contract. The respective framework is illustrated in Figure 1 and the definitions of its parameters in Table 1.

\section{Insert Table 1 about here}

\section{Insert Figure 1 about here}

The four governance parameters provide a referent [27] that will guide our empirical observation of change in contractual and relational governance. Each parameter can be subject to change through particular events [28]. For example, a contract may be renegotiated and hence be changed. This change may then be followed by new formal control being exercised based on the changed contract. This then results in sequences of events and associated changes in our governance parameters. We contend, that following these changes over time will likely result in dynamic paths of interaction along the parameters of the framework.

Having now discussed what changes (i.e. unit of change) we turn our attention to how this change occurs. These patterns are informed by two theories from evolutionary biology: Punctuated Equilibrium Model and the Theory of Biological Interaction.

\subsection{Describing Change: The Punctuated Equilibrium Model}

The punctuated equilibrium model of change incorporates two types of change: In equilibrium periods change is incremental and continuous, while in revolutionary periods change is disruptive and discontinuous. Long and stable equilibrium phases are punctuated by brief revolutionary phases [14, 29]. When several parameters of the proposed governance framework change dramatically within a short period of time, this would be a revolution. In contrast, when there are only small parameter changes over a long period of time this would be equilibrium.

IS research has used Punctuated Equilibrium a number of times to study the dynamics of a wide range of phenomena [30] [31] [32] [33]. Research on change in governance and control mechanisms has also used models that "may be characterized as punctuated equilibrium" [30, p. 180]. The focus of punctuated equilibrium is on context-driven transitions between equilibrium periods, i.e. on revolutionary change. For example, Kirsch [8] investigated the change of control choices when a project switched from one phase to another and found that contextual changes trigger changes in control. These findings are supported by Choudhury and Sabherwal [9] who found "critical events" to trigger switches from one control portfolio to another. In a similar vein, Heiskanen, Newman et al. [10] describe how governance portfolios oscillate between phases of either trust or control. 
This one-sided focus on revolutionary changes, stands in sharp contrast to an emerging incremental perspective which holds that continuous change is a critical success factor and that governance mechanisms should "be constantly in a state of being corrected" [12, 34] [11]. Although there has been some insightful research on the evolution of inter-organizational relationships [35, 36], to the best of our knowledge there has been virtually no research on continuous change of inter-organizational governance mechanisms. Furthermore, the rare work that studied incremental change of intraorganizational governance $[11,12,34]$ largely dismissed revolutionary change.

To conclude, while prior research acknowledged the importance of both disruptive as well as incremental change, its focus was on either the one or the other. Moreover, the fact that research inspired by the punctuated equilibrium model was mainly interested in revolutionary change [11] may be due to the fact that it provides a straight-forward explanatory model for these phases (revolutionary change is the outcome of large-scale contextual change and purposive organizational reaction), while an equivalent explanatory model for incremental change seems to be missing. We therefore

\subsection{The Theory of Biological Interaction}

Given its roots in evolutionary biology, the punctuated equilibrium model adopts competitive selection to drive change in equilibrium periods [20]. However, a major finding from evolutionary biology on incremental change is not incorporated in the model: While large-scale, revolutionary changes are driven by (large-scale) contextual changes (e.g. changes in earth's climate, etc.), incremental changes are not exclusively driven by small scale contextual changes. Instead biological interactions are also a major driver of incremental change [37].

According to the Theory of Biological Interaction, incremental change [37] of species is driven by biological interactions of organisms between and within species [38]. Accordingly, we suggest that incremental change of contractual and relational governance (contract, formal control, trust, informal control) is driven by interactions between and within contractual and relational governance. More specifically, each parameter of our framework takes the role of an organism. Contractual and relational governance take the role of species, the parameters that make up contractual governance (contract, formal control) and relational governance respectively (trust / norms, informal control) take the role of members of the respective species. Thus, an interaction between trust and formal control corresponds to an interaction between different species, while an interaction between trust and informal control corresponds to an interaction within a species. We distinguish five types of biological interaction by their effect on change $[15,16]^{1}$ :

(1) Mutual Beneficial: In mutual beneficial relationships between two organisms both organisms benefit from the relationship. For example leaf-cutting ants provide cut-leaves for a fungus. These cut leaves serve as a fertile soil for the fungus. In turn, the ants feed from the fungus. The consequence of mutual beneficial interactions between organisms is that they mutually shape their evolution, i.e. they co-evolve. When organisms of the same species (e.g. humans) interact for their mutual benefit we speak of cooperation, while interactions between organisms of different species (e.g. ants and fungi) are called mutualism. Applied to the governance context interactions within contractual or relational governance could be described as cooperation. As an example, trust might facilitate informal control [39], whileinformal control in turn might foster trust [40]. Thus, over time trust and control might coevolve.

\footnotetext{
${ }^{1}$ There is actually a sixth "interaction" - neutralism - which describes the case where the participants of the interactions have no effect on each other. As a consequence there is also no change deriving from that interaction. It is therefore not adopted in this study.
} 
(2) Commensalism: In a commensalistic relationship, one organism benefits, while the other is neutral. As a consequence the evolution of the benefitting organism is shaped by the evolution of the neutral organism (but not the other way around). As an example scavengers like golden jackals follow tigers to feed on the leftover of their kills. In this case the jackal benefits while the tiger is unaffected. Consequently, a growth in the tiger population will be followed by a growth in the jackal population but not the other way around. Applied to the governance context: The exercise of formal control (contractual governance) might confirm expectations and thus foster trust [41] while a change in trust might cause no change in formal control. Thus, over time the evolution of trust might depend on the exercise of control but not the other way around.

(3) Antagonism: An antagonistic relationship is detrimental for one or both of the organisms involved. In such antagonistic relationships the organisms mutually shape their evolution and therefore coevolve (typically in an evolutionary "arms race”). As an example in predator-prey relationships - such as between lion and antelope - the predator feeds on the prey. Obviously, the relationship is beneficial for the lion, but detrimental for the antelope. When faster lions occur, this will place a selection pressure on slow antelopes and conversely antelopes will grow faster over time which in turn puts a selection pressure on slow tigers, etc. Applied to the governance context, over time ever more sophisticated informal routines might evolve and replace some less-suited formal procedures. The "surviving" formal procedures might then be refined and again replace some informal routines. Thus, over time formal and informal control might co-evolve.

(4) Competition: In a competitive relationship neither of the two organisms benefits from the relationship but both use the same resources; thus the relationship is mutually detrimental. If there are not sufficient resources for all organisms, then the growth of one organism goes along with a decline of the other organism as there are fewer resources left for the other. For example, chickadees and sparrows compete for tree holes (for nesting) - thus when one finds a scarce tree hole to breed and reproduce, another may miss out and in turn this bird cannot breed and reproduce. In the context of governance, such a competitive relationship is inherent to economic approaches on control. These approaches assume that the exercise and design of controls consumes resources and therefore is costly. Thus, controllers should seek to choose the least expensive control alternative [42] at the expense of some other alternatives, e.g. informal as opposed to formal control.

(5) Amensalism: In an amensalistic relationship one organism is harmed, while the other is unaffected. As a consequence of this interaction the population of the harmed species declines, while the other remains unaffected. As an example, some bread molds produce penicillin as a bi-product which kills bacteria. Thus, the bacteria population is harmed, while the mold remains unaffected. Applied to governance, it has been argued that the exercise of formal outcome control destroys trusted relationships [40, 43], while the exercise of formal control does not require trust [44]. Thus, trust may decline while formal control is unaffected.

\section{RESEARCH METHOD}

\subsection{Method}

To answer our research questions on how and why IS outsourcing governance mechanisms change over time, we chose an exploratory case study approach[45]. Case studies are particularly suited to investigate how and why research questions [46, 47] as raised in this paper. As suggested by Eisenhardt [48], we entered the exploratory research field with pre-specified constructs: i.e. our framework represented by the four governance parameters; our distinction between incremental and disruptive changes (punctuated equilibrium); and the adoption of biological interactions to structure our findings. In concert with a process theoretic research approach, we "combine historical data 
collected through the analysis of documents and retrospective interviews with current data collected in real time" [28, p. 693].

\subsection{Case Selection}

We chose a multiple case study design consisting of four IS outsourcing projects at a single site. The case site was selected because we already had positive experiences with BANK in terms of support regarding availability of interviewees and accessibility of documents. Moreover, we wanted to assure a comparable management style and background, and that the projects are similar in size (e.g., contract volume) and functions being outsourced.

In 2009 BANK gave us the opportunity to choose four from about 90 outsourcing projects. The four cases were purposefully selected [47]. To increase the likelihood of pattern replication and variation [47] in terms of change within and between the four parameters of the framework, we needed to select cases with a minimum duration of several years. We also sought to hold those criteria constant that were not of direct theoretical interest (e.g. size and outsourced function). Based on these criteria we identified four projects which had already started, but which were still ongoing and expected to do so for the next few years. Table 2 gives an overview of the four selected cases.

\section{Insert Table 2 about here}

\subsection{Data Gathering}

For data gathering we used multiple sources [47, 48], namely a combination of interviews and document screening (e.g., contracts, OLAs, SLAs, as well as project and audit documentation). The data collection took place in two phases. Phase one from September to October 2009; phase two from July 2011 to January 2012.

Interviews: To avoid key informant bias [49] and receive different perceptions of the staff involved, we followed a multiple informants design involving managers and team members from client and vendor of each project $[47,50]$.

During the first phase of data collection 19 interviews were conducted, during the second phase 15 interviews were done (see Table 3). In each phase, we conducted two interviews with relevant members of the centralized HR vendor management department, which gave valuable insights for all projects. These are listed in the column "cross-project".

Each interview was based on a semi-structured interview guideline and took about one hour although some were considerably longer. All interviews were tape-recorded and transcribed. In addition, for each interview, short protocols containing impressions, highlights and additional interview subjects were created to prepare for subsequent interviews.

\section{Insert Table 3 about here}

Documents: For triangulation purposes we supplemented interview data with a comprehensive document analysis [51]. Document analysis was focused on contracts. In line with Goo et al. [22] we understand "contract" in a broader sense, including related documents such as service level agreements (SLAs), operating level agreements (OLAs) and so on. Analyzing contracts and other project documentation in addition to interviews resulted in three benefits. First, we were able to confirm the dates when various changes occurred; second, to document the reasons and impacts of changes in behaviors and contracts; finally, to check, whether a reported behavior is formal, because it is listed in the contract. As an example, changes in histories of operating level agreements (OLA) were very helpful to track the exact dates, reasons and contents of changes. 


\subsection{Data Analysis}

The aim of our data analysis was to uncover changes in the four governance parameters and to identify reasons for these changes. Similar to Sabherwal et al. [30] we followed a four-step data analysis process (within case analysis: steps 1-3, cross-case analysis: step 4). Each step was conducted independently by at least two researchers.

Step1 - Order Data by Time For each case, the goal was to order data by time to reveal the chronological flow of events. For this purpose, a narrative strategy [28] was applied, to prepare a chronology of governance changes from the perspective of the individuals (based on interview transcripts). This data was triangulated with document changes. Subsequently, data was consolidated and visually mapped [28] to display temporal precedence, potential influences between events, and the passage of time.

Step 2 - Coding of Documents and Transcripts Based on Framework Parameters. We used NVivo 9 to code documents and interview transcripts based on the four framework parameters (see examples in Table 4). In particular, text passages from interviews and documents that highlighted governance changes were mapped to the four parameters of our framework, whereas a parameter change could be both - a perceptual change (e.g. contract is perceived to be incomplete) and an actual change (e.g. contract was refined) [52].

\section{Insert Table 4 about here}

Step 3 - Identifying Source and Rate of Change To substantiate our supposition that incremental and disruptive changes are driven by different generative mechanisms [20] we scanned the data for two different sources of governance change, i.e. context and associated parameter changes. Thus, for each particular parameter change we analyzed whether this change was linked to changes in other parameters or the context. We will call chains of associated parameter changes interactions. For each governance change - be it driven by parameter or context changes - we then rated the magnitude of change. This allowed us to separate revolutions from equilibriums [28]: Phases showing a high rate of change (i.e., many and/or significant changes in a short period of time) represent revolutions, while phases showing a low rate of change (i.e. few and incremental changes in a long period of time) represent equilibrium phases.

Step 4 - Comparison of governance changes. To discover similarities and differences between change in equilibrium phases and change in revolutions, we compared both phases with regard to the above mentioned generative mechanisms. Moreover, we matched each observed governance interaction to the five types of biological interaction. This step revealed similarities and differences between the large number of empirically observed interactions and thus to consolidate them to four archetypical governance interaction patterns[50].

\section{RESULTS}

The following sections show the results of our study. First we describe each case separately, following roughly the chronological order of governance changes. These governance changes are characterized by changes in our four governance parameters that either represent interactions between particular parameters (incremental changes) or event-driven parameter changes (revolutions). Finally, a crosscase analysis compares and summarizes the similarities and differences between the results.

\subsection{Case Description: PAYSLIP}

ALPHA is a company, headquartered in Illinois, US. They offer worldwide HR consulting services as well as HR Business Process Outsourcing. ALPHA was mandated by BANK to take over the 
PAYSLIP processing for their Indian branch from the former service provider. The former contract with the predecessor company for the payroll processing was canceled by BANK as there were several compliance issues. As shown Table 5 there were in total eight interactions in PAYSLIP, but no revolution.

Interaction 1 During project setup around September 2008 ALPHA had to become familiar with the requirements of BANK, as BANK asked for "a proof of concept" before signing the actual contract. In the beginning, the client and vendor passed an informal process of exchanging knowledge through "many conference calls" (informal control) to create a shared understanding. This knowledge exchange extended ALPHA's initial knowledge about BANK's processes and demands, so finally "ALPHA composed a Note of Understanding (...) where they described their understanding, how the (...) payroll works". Hence, the Note of Understanding - which was a predecessor of the legal contract (contract) - was created "based on the discussions", as a member of BANK explained.

Interaction 2 and 3 Later, the Note of Understanding shaped further collaboration. As a result, working groups were defined and conducted (formal control) which gathered the necessary information to agree on the first operating level agreement (OLA version 1.0) in April 2009 and the legal contract in May 2009.

Interaction 4 May 2009 is also the month when the first payroll was carried out by ALPHA (Go Live). Since Go Live, both parties focused on building a good relationship. The relationship building took place during formal meetings. As an example, the OLA prescribes regular meetings (contract) which were conducted (formal control). A BANK manager talks about the meetings and their purpose: "our concentration (...) [was] on building the relationship with ALPHA (...). So we (...) [were] building the relationship with ALPHA. (...) ALPHA should work as an extension of our team". This example shows that formal prescribed meetings also created an environment in which social interaction could take place. As a consequence trust developed (“[now] we have a good relationship with them”).

Interaction 5 When the Go Live was over, both parties were glad to have shifted the project successfully into operational mode. This state was disturbed by the exercise of contractually agreed audit rights (formal control based on the audit rights anchored in the contract) which took place shortly after the Go Live. So far, both parties believed in the fulfillment of the policies, but the audit results portrayed a different picture. However, at this time, the relationship had reached such a mature trust level, that a senior manager from BANK described this time as: "Well, I think the relationship is going very very very well. (...) and there has been a time when (...) we had to close audit issues late in the night (...) I was able to speak to ALPHA (...) [and they] were able to turn around something for me". Hence, although problems were identified in the exercise of formal control, they were resolved in a very informal way, based on trust.

Interaction 6 Within the first version of the OLA (contract), BANK and ALPHA had agreed on a calibration phase to adjust negotiated service levels where necessary. A BANK manager notes: "then we had such a calibration phase for the service levels. Though, they were negotiated and then, within this calibration phase, it turns out, how feasible they are". After this calibration phase (formal control), BANK and ALPHA refined the service levels and released a new version of the OLA (contract).

Interaction 7 and 8 Moreover, during the last years, there are no indications of further governance adaptations. The payroll processing was slightly adapted several times, as in the Indian payroll processing yearly adjustments in taxes are common. These yearly adjustments as well as other new requirements were handled based on the Change Request process as described in the OLA.

Insert Table 5 about here 


\subsection{Case Description: HIGHPOT}

BETA, a company headquartered in California, US, offers a best-of-breed SaaS-solution for skill development and performance evaluation processes via a web based solution. In the first quarter of 2009, BANK subscribed to this service to support its employee development and performance assessment processes. Initially, BANK and BETA planned and contracted a global rollout to be finished in the second half of 2010 - however at that time the project was still a small pilot for only 600 employees (instead of the expected 40,000 plus). This delay was due to the fact that the parties underestimated the effort needed to parameterize the BETA software to meet BANK's needs.

As shown in Table 6 we examined one revolution in 2011 and a long period of incremental changes beginning in 2009 and ending with the revolution. In this period we observed seven interactions leading to incremental change in contractual and relational governance.

Interaction 1 In February 2009 the parties negotiated a contract (contract) including a so called "governance model" being very specific on formal control issues. Though not specified in detail, this governance model included rules to conduct "configuration sessions", a "weekly operational meeting", a "monthly governance forum", and a biannual "executive steering committee". For example within a configuration session (formal control) BANK formulated the idiosyncratic requirement that the documentation of employees performance review should - in addition to the standard functionality also offer a "superior's view" that documents confidential information about how superiors judge a given employee. Then software engineers from both BETA and BANK elicited what exactly had to be done to meet this requirement and documented it in a "configuration workbook" which was "signed off" and became an addendum to the contract (contract). These additional requirements were subsequently used to assess BETA's performance (formal control).

Interaction 3, 6 Conducting the rules as described in the governance model produced a trend towards a higher degree of contractual governance. For example, the contract stipulated that the governance model had to be tailored to the specifics of the project (contract). As a consequence, BANK and BETA employees met (formal control) to refine the governance model, e.g., by defining necessary meeting participants. The resulting governance model was then written into an updated and signed-off OLA (contract). A very similar interaction (6) was observed later, when the parties made adjustments to the same contractual clause to develop a new rule on multi language capability of the software.

Interaction 4 The just described trend towards a higher degree of contractual governance (following and refining the governance model) was supported by relational governance. As an example, at the end of 2009, BANK requested that BETA's datacenter should meet "minimum safety requirements". At this time BANK and BETA had established a trusted relationship (trust / norms) and started to informally exchange knowledge via spontaneous phone calls (informal control) to figure out which measures BETA should adopt to improve data center security. This led to a list of very specific measures, such as the "installation of a camera to track each person entering and leaving the datacenter". This list of measures was furthermore equipped with milestones and became subsequently an update to the OLA and thus an addendum to the contract (contract) and later served as a basis for performance evaluation (formal control).

Interaction 5 The next interaction shows how contractual and relational governance mutually shape each other: BETA was obliged by the contract to "conduct... [an] analysis" whether or not "BETA practices deviate from BANK policies" and if yes "to comply with it" (contract). In October 2010 the analysis was conducted (formal control) and revealed a number of compliance issues. However, the business model of a SaaS vendor rests on a limited degree of customization to realize economies of scale and therefore individual policy changes compromise its business model. Consequently, BETA sought a compromise and in doing so the parties relied on their trusted relationship (trust / norms) and started informally to mutually adjust (informal control): in spontaneous "phone calls" and "e-mails" the parties examined which policies BETA could tolerate and BANK could dispense without getting into trouble with their legal department. At the end of this informal adjustment process the parties 
agreed upon a new norm (trust / norms) and documented it in a "change control order", i.e. it became an addendum to the contract and subsequently served as a new basis to control BETA's policy compliance.

Interaction 7 In October 2010, BANK's internal audit routinely examined the relationship between BETA and BANK. The contract stipulated BETA to "cooperate with [BANK's] internal audit" (contract) and when the audit was carried out (formal control) a number of issues came up. One of these issues was that up to this time, BETA had refrained from monitoring contractually-defined KPIs. But after this issue was detected, BANK started to monitor (formal control) the contractuallyprescribed (contract) KPIs.

BANK did not address the other detected audit issues. Instead, following the incremental governance adaptations described above the project faced serious tensions in 2011. First, the rollout of the BETA solution was associated with serious unscheduled downtimes (5 days in Dec, 2 days in Apr, 4 days in Aug). Second, BANK and BETA decided to further postpone global rollout of a distinct module to 2012. In short, BETA did not fulfill its contractual obligations. However, BANK did not impose any penalties nor did they 'tighten the screw', instead they continued to pay for the initially contracted fee for managing 120,000 employees.

Revolutionary Period This situation changed dramatically when in August 2011 BETA published a new release that overwrote a number of code-based BANK-specific customizations which turned out to be "a tremendous problem". Most importantly, the above mentioned "superior's view" was deleted and thus employee's had "visibility to the [confidential and hidden] comments documenting the discussion about them in the HIGHPOT review meeting". When BANK realized that thousands of employees were able to see the confidential comments of their superior's about their performance, BETA had to shut down the solution immediately resulting in five weeks of unscheduled downtime. This led BANK to radically change governance in a very broad way that not only addressed the current problem but also problems of the equilibrium period. First, BANK introduced a new "Key Operating Procedure" (contract) that obliges BETA to follow a significantly more restrictive release process (formal behavior control) that forbids BETA to publish a new release without having tested it on a new BANK test platform and without approval of BANK employees ("4-eye-process to ensure $100 \%$ correct deployment to production"). Secondly, BANK "leveraged [the] existing governance model by "giving more weight to meetings" (formal control). Third, BANK was upgraded to BETA's "Critical Account Program" that incorporates a more strict "Quality Assurance Process" (formal behavior control), a "New Deployment Process" (formal behavior control) and more demanding Service Levels (formal outcome control).

While these measures are directly linked to the resolution of the underlying problem, BANK additionally changed its governance in ways that were not directly linked to the actual release problem. As an example, BANK developed a scorecard to assess BETA's performance in a number of outcome dimensions such as "open audit issues", "policy compliance" and "time-to-market". Moreover, although the "root cause" of the problem was clearly a technical problem ("code defect ... introduced in the... release"), BANK and BETA decided to spend "higher governance attention" by staffing existing meetings with more people from senior management.

After this revolution in November 2011 the measures taken proved effective ("it has improved"). In particular, the "meetings" with senior management and the strict "release process" were credited with this improvement.

Insert Table 6 about here 


\subsection{Case Description: CANDIDATE}

GAMMA was a talent management software provider founded in the UK, which was acquired by DELTA in 2008. Two years before this takeover, BANK started its partnership with GAMMA, when BANK decided to support its recruitment process with a standard software. To reach this goal BANK assessed the ASP solutions of GAMMA and DELTA. In the end BANK opted for GAMMA; "thank goodness" as one BANK team member noted. GAMMA offers a "recruiter workbench" that walks HR personnel through the application process, i.e. after having successfully passed several approval stages, the system invites applicants for interviews, schedules meetings, and finally sends out job offers or rejections.

As shown in Table 6 we examined one revolution in October 2008. Before this revolution we observed four interactions within the equilibrium.

Interaction 1 When the project started in 2006, GAMMA and BANK negotiated a contract that was very unspecific in terms of governance. Despite this shortcoming the contract supported relationship building at the beginning of the project. The contract obliged client and vendor personnel to meet in person in "configuration sessions" (contract). When these face-to-face meetings were carried out (formal control), they not only helped to set the software requirements straight, they also provided the foundation (trust / norms) for subsequent informal control: "coming out of that [the meetings]" BANK's and GAMMA's personnel started to informally adjust through the use of "telcos (...), email, [and] WebEx sessions where needed" (informal control).

Interaction 2 Subsequently, client and vendor personnel mainly relied on informal adjustments not only to solve problems in daily business but also to agree on far-reaching changes in the outsourcing project. As an example, in summer 2006, BANK and GAMMA came to a decision that would have serious consequences later in the project. The decision has its roots in the contract, which was not very specific as to what degree GAMMA's ASP solution should be customized (contract). On the one hand, GAMMA was obliged to "provide the web services in accordance with (...) any mutually agreed upon requirements", on the other hand the parties calculated only a very low fee for customization. In line with that, KPIs and SLAs included in the contract were typical for highly standardized SaaSoutsourcing focusing on response times and downtime. However, when BANK realized that GAMMA's standard SaaS solution did not suit its specific requirements, the parties conducted a meeting to carry out the contractually prescribed mutual adjustment (formal control). Within this meeting the parties began to diverge from the original contract - interestingly not by changing the contract but by agreeing upon a new performance norm (trust / norms). This new norm was different from the original spirit of the contract in that it advocated a very high degree of customization in contrast to a standardized SaaS. "It was Software as a Service [in the contract] - there was no customization. It was a one- to- many source relationship with BANK and quickly after the contract was signed that changed because there was quite a lot of customization required from the BANK process (...). That was very BANK specific and very quickly the system became very BANK specific".

Clearly, this new "customization norm" made the KPIs and SLAs, as defined in the contract, ill-fitted to the new situation. Consequently, BANK started to assess GAMMA as if it would deliver a customized solution, i.e. based on the newly negotiated norm (informal control). Note however that the contract itself with its now ill-suited KPIs and SLAs was not changed - the parties simply did not exercise the associated formal control.

Interaction 3 The character of the project had switched from standardized to customized without adapting the contract, thus the contract did not specify respective requirements and rules for implementing them (contract). Consequently, the parties had to rely on their "cooperative" relationship that was characterized by an "I help you out"-attitude (trust / norms). This in turn allowed the parties to go "straight to specific members of the development [and] configuration team" to agree on or implement distinct "configurations" (informal control). 
Interaction 4 While this departure from the original contract was perceived to be very positive in the beginning ("it was brilliant"), it also sowed the seed for a number of future problems. In November 2007, when the solution went live in Germany, India, the US and the UK, BANK was contractually guaranteed to become part of the regular release cycle (contract). However, when the first update was due the parties realized that the high degree of customization inhibited regular updates to work properly. To overcome this problem, management of both parties met (formal control) to agree upon a new norm (trust / norms). Accordingly, GAMMA was exonerated from its obligation to make BANK part of the regular release cycle, instead they were obliged to implement 30 minor bug fixes or customizations. Subsequently, GAMMA's performance when publishing releases was no longer assessed based on what still was defined in the contract, but based on this norm (informal control).

However, this new rule had the unintended side-effect that the BANK-customization "moved farther and farther away from the standard" which made each update even more complicated. However, from a governance point of view BANK and GAMMA took no specific actions to address the root-cause of the problems and as a consequence the perception of the project changed and BANK became more and more dissatisfied with GAMMA: "as soon as we were just trying to run it and trying to fix issues on a day-to-day basis, that was when it got worse".

Revolutionary Period: Despite increasing dissatisfaction, governance was only adapted incrementally from December 2007 to September 2008. This situation changed dramatically when in October 2008 GAMMA was taken over by DELTA - the company BANK specifically opted against in the vendor selection process. From a governance point of view, a direct consequence of the takeover was that knowledgeable and trusted GAMMA employees were laid off which caused the relationship to go "down hill". This had consequences for the exercise of formal and informal control. Before the takeover, GAMMA was been described as "accommodating" and willing to "spontaneously help" (informal control), but afterward they concentrated on simply fulfilling their contractual obligations.

Another direct consequence of the takeover was that BANK decided to stop the global rollout of the GAMMA application, as the new owner DELTA planned to discontinue support in 2012. In addition to these direct consequences, BANK took measures that were not directly linked to the underlying problem but rather addressed problems that had "strained" "the relationship" even before the takeover. First, contractually defined formal controls were enforced more strictly ("tighten the thumbscrew"). For example, BANK started to insist that the problems with regular releases would be failures to fulfill contractual obligations and therefore reduced the payment to the vendor, i.e., apply contractual penalties (formal control). Second, the contract itself was subject to change in two major ways. First, GAMMA was obliged to adhere to a new "build process" that formalized the introduction of new releases (formal control) and replaced the former agreement which allowed BANK to select 30 items from the total list of items (informal control). Second, BANK addressed the problem that the KPIs were still tailored to non-customized software and therefore BANK "reviewed them", designed new ones, and made them an addendum to the contract. This became the basis for subsequent formal control.

After these turbulent times the partnership slowly got back on track. This improvement was credited to the measures introduced during the revolution which prevented "issues to boil over" while at the same time assured that the project's "priorities don't change".

\section{Insert Table 7 about here}

\subsection{Case Description: GRADRECRUIT}

EPSILON is headquartered in London, UK, and started its cooperation with BANK in 2000. The relatively small start-up company EPSILON signed up BANK as one of its first large customers. In the beginning, EPSILON developed an IT solution to handle the global graduate recruiting process 
based on BANK's specific needs. This solution has been enhanced by EPSILON and transferred to a new platform (PEPPER) to sell it as an ASP solution to other customers. In 2007, BANK switched to this new platform.

As shown in Table 8 there were seven interactions in ALUMNI, but no revolution.

Since contract sign-off, the first years of collaboration between EPSILON and BANK were characterized by an intense collaboration to gather the necessary requirements for the development of the new system.

Interaction 1 In the beginning, BANK was not aware of the specific requirements and demands. Nevertheless, EPSILON was glad to have BANK as a huge customer and therefore strained to please. A project lead from BANK describes this time: "when we started working with EPSILON. They literally were building the system in a certain sense for us, so we were very lucky". The information exchange about necessary and desired functionality took place in a very informal way ("they were really flexible because we were a new client"). EPSILON was interested in learning from BANK, to build a tool which could be sold later to other customers as well, while BANK was happy to "drive some of the functionality". The project lead added that "it was very very beneficial". Hence, during the informal requirement gathering (informal control) EPSILON made sizeable concessions and promises which in turn improved trust (trust / norms). Based on an increased level of trust, BANK and EPSILON also increased the level of informal information exchange (informal control) about requirement issues and development tasks.

Interaction 2 The number of issues and tasks grew constantly during the project and so did the level of informal control. After a while, the need for structure was perceived necessary as "EPSILON really could not grapple with the large number of inquiries and issues" anymore. The frequent informal information exchange took place on different levels; for instance, BANK directly called EPSILON's developers to talk about additional requirements or issues. This informal information exchange on different organization levels had reached an extent where it was perceived as no longer acceptable. For this reason EPSILON complained about missing processes and roles and as a consequence BANK introduced a new manager into the project (contract) who collected the inquiries and issues and "then went to EPSILON, rather than many people going directly to EPSILON" (formal control). Hence, the frequent informal interaction was no longer perceived as adequate to manage the requirements gathering process. This increased the demand for more contractual governance which was established by bringing in a new role (single point of contact) which was subsequently used for approaching the vendor.

Interaction 3 The switch to the new platform (PEPPER) increased the need for more contractual governance. A BANK manager describes this situation: "when we went to the PEPPER system (...) we would expect a whole business plan, communications plan and then detail all the testing session plugged in there (...) but they didn't (...) we as a client (...) were going to manage this going forward". She explained that BANK pushed the necessary procedures and structure into the project (as foundation for formal control).

Interaction 4 Subsequently, the vendor followed the new procedures. A manager from EPSILON explained, "What usually happens - we have procedures that we go through" (exercise of formal control). These procedures are used to identify issues or requests for changes. When a necessary change comes up, EPSILON and BANK rely on their trusted relationship (trust / norms) and clarify the content and specification of the change request in an informal way (informal control). The following quote is an example of this: "often (...) [BANK comes up with] a query; they have something that needs to be fixed and (...) we have kind of an informal discussion about what we want. (...) after that (...) [I] write up a kind of informal specification putting everything together (...) and then we kind of send it back and forth". Summing up, the formal procedures are followed (formal control) to identify necessary changes. Informal control mechanisms are used to gather additional information about what BANK really wants and what EPSILON is able to do. 
Interaction 5 BANK and EPSILON had agreed on penetration tests (i.e., simulating attacks) and disaster recovery tests. These tests were conducted (performed formal controls) and revealed several issues. The IT project manager from BANK explains (Interaction 5 and 6) that „these issues were resolved - and here it is important for me to emphasize - based on the good partnership, which means not based on any contractual agreements". Hence, while the issues came up based on the exercise of formal control, the resulting issues were solved informally (informal control) based on the good relationship the parties had (trust / norms).

Interaction 7 Later in the project, a new vendor management function within BANK triggered the need to create an OLA for the purpose of standardization across all projects. Again the trusted relationship between BANK and EPSILON was used to gather the relevant information for the required OLA document which subsequently was used in day-to-day interactions. A BANK manager describes that the OLA "defines the day-to-day business - the cooperation on this level. It is a guideline; this is what the OLA is for".

\section{Insert Table 8 about here}

\subsection{Cross-case Analysis}

Across our cases we found 26 interactions between governance parameters reflecting incremental changes and two revolutions reflecting disruptive changes. In this section, we begin with a mapping which overlays the interactions observed to the five types of biological interaction to uncover idealtype governance interaction patterns. This analysis step revealed three different types of commensalistic interactions, three different types of mutual beneficial interactions and one competitive relationship. Antagonism and Amensalism interactions were not found in our data. Table 9 gives an overview of the interaction patterns observed in each case and references to the respective interactions.

\section{Insert Table 9 about here}

\subsubsection{Mutually Beneficial Interactions: Between Governance Parameters}

We found both cooperation (within species) and mutalism (between species) in all four cases.

Cooperation within the contractual governance dimension This pattern was found at HIGHPOT (I1, I3, I6, I7) and PAYSLIP (I2, I3, I6, I7, I8). In both cases the contract contains a clause (contract) that serves as a foundation for formal control. At HIGHPOT an audit review was prescribed, while at PAYSLIP the contract prescribed social interaction between client and vendor employees in several meetings. Within these meetings the parties started to socially interact and share knowledge. At HIGHPOT the exercise of the audit revealed vendor's non compliance with BANK policies. Therefore, in both cases the exercise of control led to an increase in (control-based) knowledge [41].

Cooperation within the relational governance dimension This pattern is exemplified by ALUMNI (I1). Initially, a trusted relationship (trust / norms) facilitates the exercise of informal control (informal control) which in turn fosters the development of shared norms and trust (trust / norms). Hence, informal control benefits from a trusted relationship, while trust benefits from informal control and therefore the described interaction can be considered as cooperation. Thus, trust and informal control mutually shape their evolution. This interaction replicates former findings from general management [39, 41]. Additionally, the participants used this knowledge to either add clauses, i.e. to extend the contract, or to refine clauses. Hence, both action (formal control) and foundation (contract) of 
contractual governance benefit from the relationship with the respective other. Consequently, they mutually shape each other and therefore co-evolve.

Mutualism between the contractual governance and the relational governance dimension Here (HIGHPOT, I5) the exercise of contractually-prescribed formal control revealed deficiencies in the fulfillment of contractual obligations. The detection of these deficiencies prompted the parties to informally negotiate (informal control) a new norm (trust / norms). The newly negotiated norm (trust / norms) was then being formalized and became a refinement of the contract that subsequently served as a foundation for formal control. Hence, contractual governance allowed the detection of deficiencies in the fulfillment of contractual obligations which enabled the parties to formulate the need to change governance. To derive this change the parties build on relational governance, i.e. they mutually and informally adjust (informal control) to derive a new norm (trust / norms). This norm gets formalized and therefore handed over in turn to the contractual governance dimension. As both contractual and relational governance mutually benefit from this relationship, they mutually shape each other and therefore they co-evolve.

\subsubsection{Commensalistic Interaction Between Contractual and Relational Governance}

Interactions between contractual and relational governance where either the contractual or the relational governance dimension derived a benefit while the respective other dimension remained neutral (commensalism), manifested in all four case studies. Three variants of commensalist relationships can be distinguished.

Relational governance compensates for deficiencies on the contractual governance dimension. This pattern was found at CANDIDATE. The starting points are deficiencies in the contract itself, i.e. the contract is either incomplete (I2, I3) or a contractual clause is inappropriate (I4) (contract). The detection of these deficiencies prompts the parties to informally negotiate (informal control) a new norm (trust / norms). The newly negotiated norm (trust / norms) serves as a foundation for subsequent informal control. This new relational norm can be either supplementary or contrary to contractual clauses.

Hence, in this case the detection of deficiencies in the contract enables the parties to formulate the need to change governance. This change of governance takes place in the relational governance dimension. Initially, relational governance serves as a medium to negotiate a new norm and then this norm is subsequently used as a foundation for informal control. Therefore, relational governance is changed to compensate for the deficiencies in contractual governance - while the contractual parameters in contrast to mutual beneficial interactions remain untouched. Thus, the interaction between contractual (neutral species) and relational (benefitting species) governance expressed in this variant corresponds to commensalism and therefore contractual governance shapes incremental changes in relational governance.

Contractual governance fosters the foundation of relational governance. This pattern has been observed at PAYSLIP (I4, I5), HIGHPOT (I2), CANDIDATE (I1, I4) and ALUMNI (I4, I5, and I6). Initially, the contract contains a clause that prescribes a meeting with physical co-presence. Frequently, the purpose of such a meeting was knowledge exchange between client and vendor employees or the resolution of issues. Next, meetings were carried out (formal control), where client and vendor employees started to socially interact and as a consequence trust and shared norms between the client and the vendor started to evolve (trust / norms). These subsequently allowed for more informal control. Hence, the relational dimension is shaped by the contractual dimension, while the contractual dimension remains unchanged. Thus, we can speak of commensalism where contractual governance shapes incremental changes in relational governance.

Relational governance enables the refinement of the contract. At PAYSLIP (I1) and HIGHPOT (I4), a pattern was found where in the first stage, trust-based (trust / norms) informal interaction took place 
(informal control). Interestingly, in both cases this informal interaction gave access to sticky knowledge (complex software requirements) that would otherwise be hard to get. And this knowledge was subsequently used to refine the contract when the requirements became an addendum (contract) and thereafter served as a foundation for formal control. Hence, the contractual dimension is shaped by the relational dimension, while the relational dimension is not affected in turn. Thus, this situation corresponds to commensalism where relational governance shapes incremental changes in contractual governance.

\subsubsection{Competitive Interaction Between Contractual and Relational Governance}

A third kind of interaction between contractual and relational governance has been found and can be described as competition - the situation where two organisms compete for the same limited resources and as a result the growth of one organism coincides with a decline of the other organism.

Competition between contractual and relational governance compensates for deficiencies resulting from an overemphasis of relational governance. At ALUMNI (I2, I3) client and vendor employees relied so heavily on trust-based (trust / norms) informal control that the parties desired more contractual governance. They therefore started to formalize their interaction by contractually stipulating a communication and reporting structure. As a result, informal interaction (informal control) significantly declined, while client and vendor started to follow the new contractual clause (formal control). The reason that triggered the desire to move away from relational governance was that it was perceived to be too costly and time-consuming ("we could not grapple with it") compared to contractual governance. The argument that relational governance mechanisms tend to be more costly than contractual mechanisms is in line with Thompson's administrative theory [53] and provides insight into the nature of their interaction: Both contractual and relational governance seem to utilize the same limited resources (time, money, etc.). As relational governance was perceived to be too resource-consuming, the parties started to rely on contractual governance and in turn reduced relational governance. Thus, the decline of relational governance is accompanied by an increase of contractual governance to circumvent resource consumption.

Our results show that governance changes even in phases where the context is relatively stable. Thus, contrary to prior literature $[4,5]$ changes in the context are not the exclusive driver of incremental governance change. Instead, as shown in our results four different patterns of governance interaction drive this incremental change.

\subsubsection{Revolutionary Changes as a Reaction on Cumulated Context Changes}

Two cases (CANDIDATE, HIGHPOT) suggest that phases of incremental change are punctuated by revolutionary changes: At both CANDIDATE and HIGHPOT we observed a large number of significant changes in a short period of time that affected all four governance parameters and consequently resulted in a high rate of change. Both revolutions observed were triggered by strong events - a vendor takeover at CANDIDATE and the introduction of a "buggy" release that overwrote all BANK-specific customizations and more importantly declassified confidential information at HIGHPOT. This need for strong events that trigger a revolution is in line with punctuated equilibrium's inertia assumption [14]. However, the consequential changes were not all directed to absorb the influence of the trigger, i.e. to adapt to the new situation. Instead, the changes made were also retroactive adaptations to formerly non-addressed problems that took place in equilibrium periods but that seemed to be too weak to trigger a revolution. Moreover, at both CANDIDATE and HIGHPOT the parties resorted to the initial objectives of the contract by partially reversing those governance actions and routines that emerged during the evolutionary phase. 


\section{DISCUSSION AND IMPLICATIONS}

As noted above, our results explain change in equilibrium periods as a result of internal dynamics between the four parameters of our framework and revolutionary change as being triggered by strong events. Our study offers a number of important theoretical and practical implications.

\subsection{Framework Enables a "Micro-View” on Governance Change}

We have proposed a framework to better understand change in contractual and relational governance. The framework divides contractual and relational governance into foundation and action. This framework conceptually contributes to research on contractual and relational governance in two respects. First, prior research has shown conceptual differences by either emphasizing the foundation of governance mechanisms (i.e., trust / norms, contract) [23] [21], or the derived actions (i.e., formal and informal control) $[6,54]$. Our framework integrates these separate perspectives and offers new insights into the interactions between governance parameters. Second, while integrating these different perspectives the framework does not simply merge them, instead it acknowledges the conceptual distinctiveness of each parameter by keeping them separate. This contributes to more recent claims holding that trust and informal control, as well as contract and formal control should be kept separate $[2,40,55]$.

Additionally, our conceptual framework serves first and foremost as a tool to describe governance change. The framework enables the reconstruction of interaction patterns of governance change that occur as paths along and across its dimensions. In doing so, we believe we were the first to empirically capture the complex interdependencies between all four parameters of contractual and relational governance as described in the literature [39-41]. Our empirical investigation does not analyze change from one high-level governance portfolio to another; rather it provides a micro-view on the emergence, adaptation and exercise of governance mechanisms. Our study provides the basis to "more closely examine the dynamics" of governance [56, p.72]. The significance of the dynamic interaction patterns is taken up in the next section.

\subsection{Theory Extension: Interaction Patterns between Governance Parameters}

The simultaneous analysis of small-scale, incremental change and large-scale disruptive change allowed us to trace back different rates of change to different drivers of change. We found that, just like biological interactions drive incremental biological evolution [37], so too do interactions between and within contractual and relational governance drive incremental change of governance. This means that incremental change of governance mechanisms cannot be exclusively explained with incremental context changes. We have identified three governance interaction patterns. Each of them has predictable consequences for incremental governance change: Mutual beneficial interactions breed coevolution, commensalism interaction leads to changes in the benefitting governance species, and competition to the decline of one governance species in favor of the other. Thus, these patterns are a first step to explaining incremental governance change that is independent from the context. While our results do not deny the importance of context changes, they add an additional driver explaining incremental governance change - internal dynamics between governance parameters.

These results add to both the punctuated equilibrium model of change [57] as well as to control theory $[44,58]$. Punctuated equilibrium figures "competitive selection" [20, p. 530] to drive incremental 
change. Notably, while we also have identified competition for resources as a driving force of governance change, other competitive interactions like antagonism and amensalism were not found in our data. Instead our results challenge the assumption that different types of governance mechanisms predominantly compete or even harm each other. On the contrary, we have found mutually beneficial (cooperation and mutualism) and commensalist interactions between governance parameters, i.e. we have found three patterns of interactions where at least one parameter benefits. Thus, they extend punctuated equilibrium with another three interaction types - besides competition - that explain change. First, mutual beneficial interactions illuminate the dependency of governance parameters, in that they mutually build on each other over time, striving for higher levels of maturity in a particular dimension (e.g. more complete contracts) and thereby even reinforcing this movement towards a higher level of maturity. Second, in a commensalistic interaction an unsatisfactory level of one dimension serves as a motivating force for enhancing another governance dimension and thereby again opens up the possibility to reach a higher degree of maturity.

It is important to note that these patterns may either be actively sought by the stakeholders involved or emerge somewhat unconsciously (e.g. trust evolves as a consequence of informal meetings without the explicit intention to increase trust), i.e. they may be seen as active or passive incremental adaptations. This thought is expanded upon in implications for practice.

\subsection{Theory Extension: Hidden Inter-connectedness of Equilibrium and Revolution}

In two cases (CANDIDATE, HIGHPOT) long periods of evolutionary change were punctuated by short periods of revolutionary upheaval [14]. This finding is consistent with the basic punctuated equilibrium model and stresses the usefulness of punctuated equilibrium to describe human affairs [59]. Our results also demonstrate that revolutions are triggered by

37

strong events and as a consequence contractual and relational governance are significantly and purposefully changed. This is in line with control theory [44] and replicates former findings on disruptive change of governance mechanisms $[8,9]$.

In addition our results highlight the inter-connectedness of equilibriums and revolutions. While revolutions are triggered by events, the changes made are not exclusively directed to absorb the influence of the triggers, instead they are also retroactive adaptations to formerly non-addressed context changes and problems of the preceding equilibrium. Thus, context changes accumulate over time and thereby connect revolutions to equilibriums. Moreover, in revolutions the parties resort to the initial objectives of the contract by partially reversing those governance actions and routines that emerged during the evolutionary phase. These complex connections between evolutions and revolutions bear potential benefits and risks. On the one hand, change driven by dynamics between governance parameters breeds highly specific governance mechanisms that are able to resolve highly specific problems arising in the process of service delivery. On the other hand change driven by dynamic interactions may unfold a self-perpetuating character and thus detract from the initial outsourcing goals.

The interactions between governance parameters produce stable, informal routines and even contractually institutionalized formal control. Thus deviations from original outsourcing goals may even be reinforced by self-perpetuating interactions. Thus, the "big picture" is neglected, in favor of specific problem solving. This became a problem at CANDIDATE when further customization needed to be limited and performance evaluation to be reconciled with the specific needs of a now nonstandardized software solution. It appeared that a revolutionary event was almost necessary to become aware of and get out of this deadlocked situation, i.e., to reduce the gap between initial outsourcing 
goals (standardized software solution) by partially reversing those governance actions and routines that had merged during equilibrium.

The opposite is the case with revolutions. On the one hand, revolutionary changes restore coalignment with the context and the initial outsourcing objectives. Thus revolutionary change is directed towards superior goals. On the other hand, the highly-specific governance mechanisms that incrementally emerged as an outcome of governance interactions were partially reversed. This may be problematic as contractual and relational governance are important storages for organizational knowledge [60]. Thus, the solutions to specific problems are neglected, in favor of the "big picture". At CANDIDATE, a strict build process was introduced as a reaction to the revolution. Before that, the parties used an informal routine that had slowly evolved over time and that allowed the parties to find feasible solutions for BANK's idiosyncratic requirements. In contrast, the new rigid build process no longer allowed for idiosyncratic and informal adjustments. Instead, changes must be in line with the contractually agreed objectives.

The previous discussion shows that it would be favorable to combine the benefits of both selfperpetuating incremental change and goal-driven revolutionary change without suffering from associated risks. How this could be achieved is subject to the practical implications of this study.

\subsection{Implications for Practice}

Our study offers three important implications for practice. First, as interactions between and within contractual and relational governance breed highly specific governance mechanisms practitioners should deliberately make use of these interactions. They can do this by designing governance mechanisms that are tailored to stimulate these interactions.

One option would be to actively foster social interaction between client and vendor employees as it is essential for many interaction patterns: Social interaction between client and vendor employees is critical to building trusted relationships, to agree on new norms, and to share complex or even sticky knowledge. Following on from this, trusted relationships are the foundation to exercise informal control, norms may be formalized and serve as a foundation for formal control, and the improved knowledge can be used to refine the contract. Thus, the deliberate advancement of social interactions might stimulate a number of beneficial interactions between governance parameters. A common way to foster social interaction is by prescribing meetings or regular conference calls.

However, it is also important to avoid those self-perpetuating interactions that can guide the project away from its initial objective. Thus, the second implication urges senior management to carefully monitor the development of incremental governance adaptations to prevent a gap between the direction of incremental governance changes and initial project objectives.

Finally, in case a revolution can not be prevented, senior mangers should be careful in taking farreaching measures which may contradict the advantages of problem- and situation-specific incremental governance adaptations which were purposefully implemented before. Hence, in case of a revolution, we urge managers to explicitly address the trigger of the revolution, but not to overreact and reverse numerous meaningful incremental governance adaptations.

\subsection{Limitations and Future Research}

We recognize that this study has a number of limitations, which should be addressed by future research. First, we used data from one client company only. Although using multiple projects allows for some degree of generalization, we recognize the need for replication studies in other companies to either discover additional patterns of interaction or to confirm the findings of this study. This study is 
based on two rounds of interviews as well as a large amount of documents. Nevertheless, we were not able to retrace the complete timeline of these projects without gaps. Future studies may rely on even more fine-grained data and trace all governance changes over time, e.g., by making use of participative research approaches where the researcher accompanies a project from start to finish [e.g., $61,62]$. We identified different patterns of interaction between and within contractual and relational governance. These patterns might help to clarify the recent debate on complementarity and substitution of governance mechanisms [7, 22, 23]. While mutualism might be an indicator of a complementary relationship, competition might indicate a substitutional relationship. As these interaction patterns have been spread over time in our cases, the relationship between contractual and relational governance may also be subject to change over time. There is a need for future research to empirically substantiate this supposition. These studies should also pay special attention to a methodological problem that biologist frequently face when analyzing commensalistic interactions: These relationships might also be mutualistic in ways that have not yet been detected, e.g. because the feedback interaction has not yet occurred, it is too subtle to observe or it cannot be clearly mapped to a triggering interaction.

Although we recognize our research has a number of limitations, we nevertheless feel that a significant contribution to outsourcing governance has been offered. We trust that other researchers will continue building upon the knowledge gained from our research. 


\section{REFERENCES}

1. Gopal, A., T. Mukhopadhyay, and M. Krishnan, The role of software processes and communication in offshore software development. Communications of the ACM, 2002. 45(4): p. 193-200.

2. Sabherwal, R., The role of trust in outsourced IS development projects. Communications of the ACM, 1999. 42(2): p. 80-86.

3. Lee, J., S. Miranda, and Y. Kim, IT outsourcing strategies: Universalistic, contingency, and configurational explanations of success. Information Systems Research, 2004. 15(2): p. 110 131.

4. Grover, V., M. Cheon, and J. Teng, The effect of service quality and partnership on the outsourcing of information systems functions. Journal of Management information systems, 1996. 12(4): p. 89-116.

5. Kirsch, L., Portfolios of control modes and IS project management. Information Systems Research, 1997. 8(3): p. 215.

6. Kirsch, L.J., et al., Controlling information systems development projects: The view from the client. Management Science, 2002: p. 484-498.

7. Tiwana, A., Systems Development Ambidexterity: Explaining the Complementary and Substitutive Roles of Formal and Informal Controls. Journal of Management Information Systems, 2010. 27(2): p. 87-126.

8. Kirsch, L.J., Deploying common systems globally: The dynamics of control. Information Systems Research, 2004. 15(4): p. 374-395.

9. Choudhury, V. and R. Sabherwal, Portfolios of control in outsourced software development projects. Information Systems Research, 2003. 14(3): p. 291.

10. Heiskanen, A., M. Newman, and M. Eklin, Control, trust, power, and the dynamics of information system outsourcing relationships: A process study of contractual software development. The Journal of Strategic Information Systems, 2008. 17(4): p. 268-286.

11. Brown, S.L. and K.M. Eisenhardt, The art of continuous change: Linking complexity theory and time-paced evolution in relentlessly shifting organizations. Administrative Science Quarterly, 1997. 24(1): p. 1-34.

12. Cardinal, L.B., S.B. Sitkin, and C.P. Long, Balancing and rebalancing in the creation and evolution of organizational control. Organization Science, 2004: p. 411-431.

13. Barker, J.R., Tightening the iron cage: Concertive control in self-managing teams. Administrative Science Quarterly, 1993: p. 408-437.

14. Gersick, C.J.G., Revolutionary change theories: A multilevel exploration of the punctuated equilibrium paradigm. Academy of Management Review, 1991: p. 10-36.

15. Thompson, J.N., The Co-Evolutionary Process. 1994: University of Chicago Press.

16. Thompson, J.N., Interaction and coevolution. 1982: Wiley New York.

17. Dibbern, J., et al., Information systems outsourcing: a survey and analysis of the literature. ACM SIGMIS Database, 2004. 35(4): p. 6-102.

18. Lacity, M., S. Khan, and L. Willcocks, A review of the IT outsourcing literature: Insights for practice. The Journal of Strategic Information Systems, 2009. 18(3): p. 130-146.

19. Markus, M.L. and D. Robey, Information technology and organizational change: causal structure in theory and research. Management Science, 1988. 34(5): p. 583-598.

20. Van de Ven, A.H. and M.S. Poole, Explaining development and change in organizations. Academy of management review, 1995: p. 510-540.

21. Lee, Y. and S. Cavusgil, Enhancing alliance performance: The effects of contractual-based versus relational-based governance. Journal of Business Research, 2006. 59(8): p. 896-905. 
22. Goo, J., et al., The role of service level agreements in relational management of information technology outsourcing: An empirical study. MIS Quarterly, 2009. 33(1): p. 119-145.

23. Poppo, L. and T. Zenger, Do formal contracts and relational governance function as substitutes or complements? Strategic management journal, 2002. 23(8): p. 707-725.

24. Gopal, A. and K. Sivaramakrishnan, On vendor preferences for contract types in offshore software projects: the case of fixed price vs. time and materials contracts. Information Systems Research, 2008. 19(2): p. 202-220.

25. Cropanzano, R. and M.S. Mitchell, Social exchange theory: An interdisciplinary review. Journal of Management, 2005. 31(6): p. 874-900.

26. McEvily, B., V. Perrone, and A. Zaheer, Trust as an organizing principle. Organization science, 2003: p. 91-103.

27. Nutt, P.C., Types of organizational decision processes. Administrative Science Quarterly, 1984. 29(3): p. 414-450.

28. Langley, A., Strategies for theorizing from process data. The Academy of Management Review, 1999. 24(4): p. 691-710.

29. Romanelli, E. and M.L. Tushman, Organizational transformation as punctuated equilibrium: An empirical test. Academy of Management Journal, 1994. 37(5): p. 1141-1166.

30. Sabherwal, R., R. Hirschheim, and T. Goles, The dynamics of alignment: Insights from a punctuated equilibrium model. Organization Science, 2001: p. 179-197.

31. Porra, J., R. Hirschheim, and M.S. Parks, The history of texaco's corporate information technology function: a general systems theoretical interpretation. MIS Quarterly, 2005: p. 721-746.

32. Silva, L. and R. Hirschheim, Fighting against windmills: Strategic information systems and organizational deep structures. Management Information Systems Quarterly, 2007. 31(2): p. 7.

33. Lyytinen, K. and M. Newman, Explaining information systems change: a punctuated sociotechnical change model. European Journal of Information Systems, 2008. 17(6): p. 589-613.

34. Sitkin, S.B., Learning through failure: The strategy of small losses. Research in organizational behavior, 1992. 14(1): p. 231-266.

35. Ariño, A. and J. de la Torre, Learning from failure: Towards an evolutionary model of collaborative ventures. Organization Science, 1998. 9(o.Nr.): p. 3.

36. Borch, O., The process of relational contracting: developing trust-based strategic alliances among small business enterprises. Advances in strategic Management, 1994. 10: p. 113-135.

37. Sahney, S., M.J. Benton, and P.A. Ferry, Links between global taxonomic diversity, ecological diversity and the expansion of vertebrates on land. Biology letters, 2010. 6(4): p. 544-547.

38. Whitham, T.G., et al., A framework for community and ecosystem genetics: from genes to ecosystems. Nature Reviews Genetics, 2006. 7(7): p. 510-523.

39. Inkpen, A. and S. Currall, The coevolution of trust, control, and learning in joint ventures. Organization Science, 2004: p. 586-599.

40. Das, T.K. and B. Teng, Between trust and control: developing confidence in partner cooperation in alliances. The Academy of Management review, 1998. 23(3): p. 491-512.

41. Sydow, J. and A. Windeler, Knowledge, trust, and control: Managing tensions and contradictions in a regional network of service firms. International Studies of Management and Organization, 2003. 33(2): p. 69-100.

42. Eisenhardt, K.M., Control: Organizational and economic approaches. Management Science, 1985. 31(2): p. 134-149.

43. Reed, M., Organization, trust and control: a realist analysis. Organization Studies, 2001. 22(2): p. 201. 
44. Ouchi, W.G., A conceptual framework for the design of organizational control mechanisms. Management Science, 1979: p. 833-848.

45. Benbasat, I., D.K. Goldstein, and M. Mead, The Case Research Strategy in Studies of Information Systems. Management Information Systems Quarterly, 1987. 11(3): p. 369-386.

46. Dubé, L. and G. Paré, Rigor in information systems positivist case research: Current practices, trends, and recommendations. MIS Quarterly, 2003: p. 597-636.

47. Yin, R.K., Case study research: Design and methods. Vol. 5. 2009: Sage Publications, Inc.

48. Eisenhardt, K., Building theories from case study research. Academy of management review, 1989. 14(4): p. 532-550.

49. Kumar, N., L.W. Stern, and J.C. Anderson, Conducting interorganizational research using key informants. Academy of Management Journal, 1993: p. 1633-1651.

50. Miles, M. and A. Huberman, Qualitative data analysis: An expanded sourcebook. 1994, London: Sage Publications.

51. Patton, M.Q., Qualitative Research and Evaluation Methods. 3 ed. 2002, Thousand Oaks: Sage Publications.

52. Poole, M.S. and A.H. Van de Ven, Handbook of organizational change and innovation. 2004: Oxford University Press, USA.

53. Thompson, J.D., Organizations in Action. 1967, New York: McGraw-Hill.

54. Tiwana, A. and M. Keil, Control in Internal and Outsourced Software Projects. Journal of Management Information Systems, 2009. 26(3): p. 9-44.

55. Kirsch, L., Deploying common systems globally: The dynamics of control. Information Systems Research, 2004. 15(4): p. 374-395.

56. Sitkin, S.B., L.B. Cardinal, and K.M. Bijlsma-Frankema, A configurational theory of control, in Organizational Control. 2010, Cambridge University Press: Cambridge, UK. p. 51-79.

57. Tushman, M.L. and E. Romanelli, Organizational evolution: A metamorphosis model of convergence and reorientation. Research in organizational behavior, 1985.

58. Ouchi, W.G., Markets, bureaucracies, and clans. Administrative Science Quarterly, 1980: p. 129-141.

59. Prindle, D.F., Importing Concepts from Biology into Political Science: The Case of Punctuated Equilibrium. Policy Studies Journal, 2012. 40(1): p. 21-44.

60. Kieser, A. and U. Koch, Organizational Learning through rule adaptation: from the behavioral theory to transactive organizational learning. The Economics of Choice, Change and Organization, 2007: p. 237-258.

61. Baskerville, R.L. and A.T. Wood-Harper, A critical perspective on action research as a method for information systems research. Journal of Information Technology, 1996. 11(3): p. 235-246.

62. Avison, D.E., et al., Action research. Communications of the ACM, 1999. 42(1): p. 94-97.

63. Jaworski, B.J., Toward a theory of marketing control: environmental context, control types, and consequences. The Journal of Marketing, 1988: p. 23-39. 
TABLES AND FIGURES

\begin{tabular}{|l|l|l|}
\hline Parameter & Definition & Based on \\
\hline Trust/Norms & $\begin{array}{l}\text { Trust refers to the positive expectations about another party's } \\
\text { intention or behaviors. } \\
\text { Relational norms refer to expected behaviors that are partially } \\
\text { shared by a group and directed toward collective group goals. }\end{array}$ & [22, 26] \\
\hline Informal Control & $\begin{array}{l}\text { Informal control refers to control that is unwritten and typically } \\
\text { "worker-initiated”. }\end{array}$ & {$[55,63]$} \\
\hline Contract & $\begin{array}{l}\text { A contract is a written document, accepted as binding by } \\
\text { controlees, and capable of deriving control actions. }\end{array}$ & {$[22]$} \\
\hline Formal Control & $\begin{array}{l}\text { Formal control covers formally documented and management } \\
\text { initiated mechanisms. }\end{array}$ & $\begin{array}{l}{[9,44,55,} \\
63]\end{array}$ \\
\hline
\end{tabular}

Table 1: Definitions of Governance Parameters

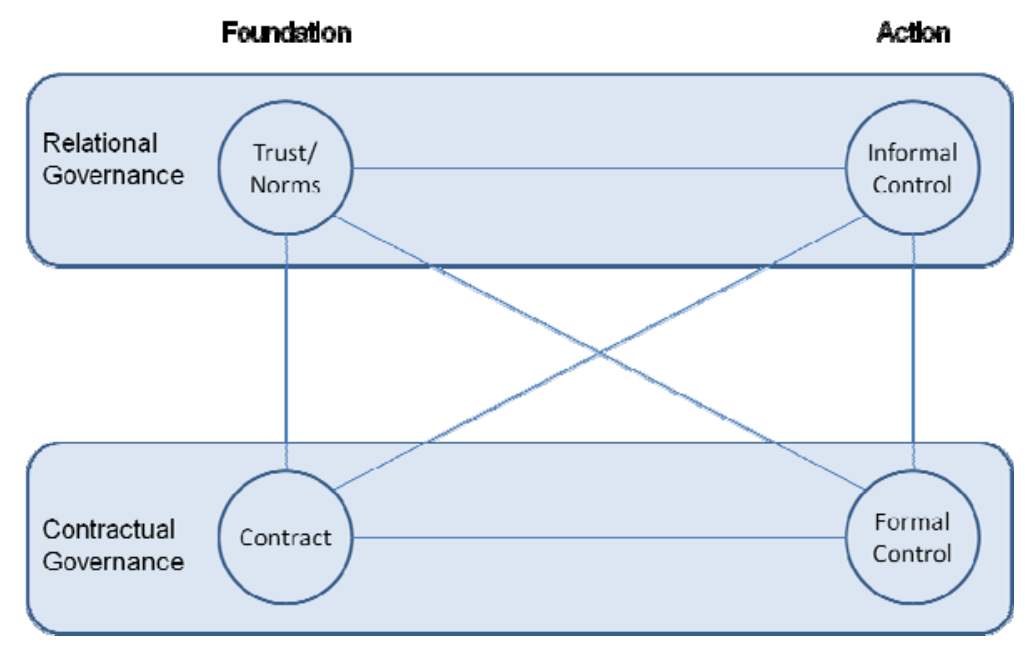

Figure 1: Four-parameter Framework of Governance Change

\begin{tabular}{|c|c|c|c|c|}
\hline & ALUMNI & CANDIDATE & HIGHPOT & PAYSLIP \\
\hline Client & \multicolumn{4}{|c|}{$\begin{array}{l}\text { "BANK”: Big globally acting German bank. All projects stem from the human } \\
\text { resource (HR) department. Project management is decentralized, supported by a } \\
\text { central vendor management. }\end{array}$} \\
\hline Project size & \multicolumn{4}{|c|}{ All projects cost about 0.5 to 1.5 million US dollar per year. } \\
\hline Vendor & $\begin{array}{l}\text { Vendor located in } \\
\text { the UK. }\end{array}$ & $\begin{array}{l}\text { The initial vendor } \\
\text { (UK) was taken } \\
\text { over by its } \\
\text { competitor (USA) } \\
\text { during the project. }\end{array}$ & $\begin{array}{l}\text { Vendor located in } \\
\text { the USA. }\end{array}$ & $\begin{array}{l}\text { Vendor located in } \\
\text { the USA with a } \\
\text { material branch in } \\
\text { India. }\end{array}$ \\
\hline $\begin{array}{l}\text { Place of } \\
\text { delivery and } \\
\text { management }\end{array}$ & $\begin{array}{l}\text { Project carried out } \\
\text { by people in the } \\
\text { US, UK and } \\
\text { Germany. Solution } \\
\text { rolled out } \\
\text { worldwide. }\end{array}$ & $\begin{array}{l}\text { Project carried out } \\
\text { by people in the } \\
\text { US, UK, India and } \\
\text { Germany. Solution } \\
\text { was planned to be } \\
\text { rolled out }\end{array}$ & $\begin{array}{l}\text { Project carried out } \\
\text { by people in the } \\
\text { US, UK and } \\
\text { Germany. Solution } \\
\text { rolled out } \\
\text { worldwide. }\end{array}$ & $\begin{array}{l}\text { Project carried out } \\
\text { by people in } \\
\text { Singapore and } \\
\text { India. PAYSLIP } \\
\text { processing only for } \\
\text { the Indian branch }\end{array}$ \\
\hline
\end{tabular}




\begin{tabular}{|l|l|l|l|l|}
\hline & & worldwide. & & of BANK. \\
\hline $\begin{array}{l}\text { Project } \\
\text { duration }\end{array}$ & $\begin{array}{l}\text { The still ongoing } \\
\text { project started in } \\
\text { 2001 and the } \\
\text { former individual } \\
\text { development } \\
\text { project was } \\
\text { switched to a } \\
\text { standardized } \\
\text { platform in 2007. }\end{array}$ & $\begin{array}{l}\text { The still ongoing } \\
\text { project started in } \\
\text { 2006. }\end{array}$ & $\begin{array}{l}\text { The still ongoing } \\
\text { project started in } \\
2009 .\end{array}$ & $\begin{array}{l}\text { The still ongoing } \\
\text { project started in } \\
2008 .\end{array}$ \\
\hline $\begin{array}{l}\text { Focus of } \\
\text { investigation }\end{array}$ & 2006-2010 & 2006-2010 & 2009-2011 & $2008-2010$ \\
\hline $\begin{array}{l}\text { Project focus } \\
\text { during time of } \\
\text { investigation }\end{array}$ & $\begin{array}{l}\text { Preparation to } \\
\text { switch from } \\
\text { individually } \\
\text { developed } \\
\text { software solutions } \\
\text { to a standardized } \\
\text { platform. }\end{array}$ & $\begin{array}{l}\text { Customization of a a } \\
\text { new tool to replace } \\
\text { the ALUMNI. }\end{array}$ & $\begin{array}{l}\text { Customization of a } \\
\text { new tool to support } \\
\text { BANKs global } \\
\text { skill development } \\
\text { and performance } \\
\text { assessment } \\
\text { processes. }\end{array}$ & $\begin{array}{l}\text { Transfer from the } \\
\text { previous payroll } \\
\text { processing } \\
\text { provider to } \\
\text { HEWITT. }\end{array}$ \\
\hline
\end{tabular}

Table 2: Case Description

\begin{tabular}{|l|c|c|c|c|c|}
\hline $\begin{array}{l}\text { \# Interviews } \\
\text { (Total: 34) }\end{array}$ & ALUMNI & CANDIDATE & HIGHPOT & PAYSLIP & $\begin{array}{l}\text { Cross- } \\
\text { project }\end{array}$ \\
\hline 2009 & 4 & 4 & 3 & 6 & 2 \\
\hline $2011 / 2012$ & 3 & 2 & 5 & 3 & 2 \\
\hline Total & 7 & $\mathbf{6}$ & $\mathbf{8}$ & $\mathbf{9}$ & $\mathbf{4}$ \\
\hline \multicolumn{7}{|l|}{$\begin{array}{l}\text { \# Distinct } \\
\text { Interviewees } \\
\text { (Total: 28) }\end{array}$} & ALUMNI & CANDIDATE & HIGHPOT & PAYSLIP & $\begin{array}{l}\text { Cross- } \\
\text { project }\end{array}$ \\
\hline 2009-2012 & $\mathbf{6}$ & & & $\mathbf{8}$ \\
\hline
\end{tabular}

Table 3: Number of Interviews and Distinct Interview Partners

\begin{tabular}{|c|c|c|}
\hline $\begin{array}{l}\text { Framework } \\
\text { Parameter } \\
\text { (Construct) }\end{array}$ & Exemplary Quote for Parameter & Exemplary Quote for Change in Parameter \\
\hline Contract & $\begin{array}{l}\text { "The OLA was part of the contract." } \\
\text { "here was a second agreement which } \\
\text { was signed by another group within } \\
\text { BANK which was then brought into } \\
\text { our overall BANK contract." }\end{array}$ & $\begin{array}{l}\text { "That section [of the OLA] needed to be } \\
\text { completed. (...) I finally had a chance to look } \\
\text { at it a few weeks ago. Now it is finished." } \\
\text { „create an addendum to a contract” }\end{array}$ \\
\hline $\begin{array}{l}\text { Formal } \\
\text { Control }\end{array}$ & $\begin{array}{l}\text { "We do have them [Service Levels] in } \\
\text { place and we do have a system where } \\
\text { we track them." } \\
\text { "Our monthly governance calls" } \\
\text { "I have [contractually prescribed] }\end{array}$ & $\begin{array}{l}\text { "Now we (...) just go through that process.” } \\
\text { „[a meeting] turned out to be very helpful, } \\
\text { this is why we now also have these weekly } \\
\text { meetings with the VENDOR project } \\
\text { manager" }\end{array}$ \\
\hline
\end{tabular}




\begin{tabular}{|c|c|c|}
\hline & weekly meetings with (...)” & $\begin{array}{l}\text { „as a result of the audit, our monthly } \\
\text { governance calls (...) became more } \\
\text { important” }\end{array}$ \\
\hline $\begin{array}{l}\text { Trust / } \\
\text { Norms }\end{array}$ & $\begin{array}{l}\text { "I would say that I trust them" } \\
\text { "The relationship on trust (...) } \\
\text { play[s] a very great role" } \\
\text { "Generally we trust them" }\end{array}$ & $\begin{array}{l}\text { "Certainly it [the relationship] went down } \\
\text { hell" } \\
\text { "the releases impacted our ability to trust the } \\
\text { system" } \\
\text { "[it] can't be solved at this [weekly] level } \\
\text { and then (...) it is sort of agreed at an } \\
\text { executive level the solution that we gonna do } \\
\text { there." }\end{array}$ \\
\hline $\begin{array}{l}\text { Informal } \\
\text { Control }\end{array}$ & $\begin{array}{l}\text { "It is very important, that we talk } \\
\text { even it might be just for a few } \\
\text { minutes" } \\
\text { "It is more of an informal thing" }\end{array}$ & $\begin{array}{l}\text { "No, I am not [involved in the day-to-day } \\
\text { governance anymore]. Once the project went } \\
\text { into the live-mode, they don't come to me } \\
\text { anymore." } \\
\text { "if there are problems then we contact them } \\
\text { directly. Now (...) we have permanently calls } \\
\text { between NAME and us." } \\
\text { "if there are new reports to be implemented, } \\
\text { then there are ad-hoc meetings in addition" }\end{array}$ \\
\hline
\end{tabular}

Table 4: Coding of Constructs

\begin{tabular}{|c|c|c|c|}
\hline $\begin{array}{l}\text { Case / } \\
\text { Interac } \\
\text { tion }\end{array}$ & Illustration & $\begin{array}{l}\text { Description } \\
\mathrm{T} / \mathrm{N}=\text { trust and relational norms, } \mathrm{C}=\text { contract, } \mathrm{IC}= \\
\text { informal control, } \mathrm{FC}=\text { formal control }\end{array}$ & Pattern \\
\hline $\begin{array}{l}\text { PAYSL } \\
\text { IP } \\
\text { Interacti } \\
\text { on } 1\end{array}$ & & $\begin{array}{l}\text { IC: Informal knowledge exchange via spontaneous } \\
\text { phone calls take place to specify requirements } \\
\text { C: Note of Understanding is created, which is the basis } \\
\text { for collaboration (as contract does not yet exist) }\end{array}$ & $\begin{array}{l}\text { Commens } \\
\text { alism }\end{array}$ \\
\hline $\begin{array}{l}\text { PAYSL } \\
\text { IP } \\
\text { Interacti } \\
\text { on } 2\end{array}$ & & $\begin{array}{l}\text { C: Note of Understanding prescribes working groups } \\
\text { FC: Within working groups necessary information is } \\
\text { exchanged to create an OLA } \\
\text { C: OLA version } 1.0 \text { is created in April } 2009\end{array}$ & $\begin{array}{l}\text { Cooperati } \\
\text { on }\end{array}$ \\
\hline $\begin{array}{l}\text { PAYSL } \\
\text { IP } \\
\text { Interacti } \\
\text { on } 3\end{array}$ & & $\begin{array}{l}\text { C: Note of Understanding prescribes working groups } \\
\text { FC: Within working groups necessary information is } \\
\text { exchanged to create the contract } \\
\text { C: Legal contract is created in May } 2009\end{array}$ & $\begin{array}{l}\text { Cooperati } \\
\text { on }\end{array}$ \\
\hline
\end{tabular}




\begin{tabular}{|c|c|c|c|}
\hline $\begin{array}{l}\text { PAYSL } \\
\text { IP } \\
\text { Interacti } \\
\text { on } 4\end{array}$ & 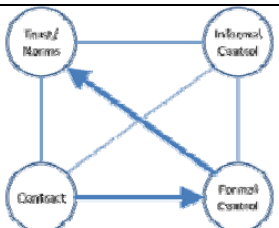 & $\begin{array}{l}\text { C: OLA prescribes regular meetings } \\
\text { FC: When meetings take place social interaction is } \\
\text { directed towards an improvement of the relationship } \\
\text { T/N: Trust was build and manifests in a relationship } \\
\text { perceived as being good }\end{array}$ & $\begin{array}{l}\text { Commens } \\
\text { alism }\end{array}$ \\
\hline $\begin{array}{l}\text { PAYSL } \\
\text { IP } \\
\text { Interacti } \\
\text { on } 5\end{array}$ & & $\begin{array}{l}\text { C: Contract prescribes audit rights } \\
\text { FC: Audit is conducted and reveals several compliance } \\
\text { issues } \\
\text { T: Trusted relationship is used } \\
\text { IC: An urgent audit issues is resolved informally }\end{array}$ & $\begin{array}{l}\text { Commens } \\
\text { alism }\end{array}$ \\
\hline $\begin{array}{l}\text { PAYSL } \\
\text { IP } \\
\text { Interacti } \\
\text { on } 6\end{array}$ & & $\begin{array}{l}\text { C: OLA } 1.0 \text { prescribes a calibration phase to evaluate } \\
\text { service level adequacy } \\
\text { FC: Necessary service level changes are assessed } \\
\text { C: New OLA version (1.1) is released, containing } \\
\text { refined service levels }\end{array}$ & $\begin{array}{l}\text { Cooperati } \\
\text { on }\end{array}$ \\
\hline $\begin{array}{l}\text { PAYSL } \\
\text { IP } \\
\text { Interacti } \\
\text { on } 7\end{array}$ & & $\begin{array}{l}\text { C: OLA prescribes a process for change requests } \\
\text { FC: Change request process is followed } \\
\text { C: Contract is refined }\end{array}$ & $\begin{array}{l}\text { Cooperati } \\
\text { on }\end{array}$ \\
\hline $\begin{array}{l}\text { PAYSL } \\
\text { IP } \\
\text { Interacti } \\
\text { on } 8\end{array}$ & & $\begin{array}{l}\text { C: OLA prescribes a process for change requests } \\
\text { FC: Change request process is followed } \\
\text { C: Contract is refined }\end{array}$ & $\begin{array}{l}\text { Cooperati } \\
\text { on }\end{array}$ \\
\hline
\end{tabular}

Table 5: Case Results: PAYSLIP

\begin{tabular}{|c|c|c|c|}
\hline $\begin{array}{l}\text { Case / } \\
\text { Interacti } \\
\text { on }\end{array}$ & Illustration & $\begin{array}{l}\text { Description } \\
\mathrm{T} / \mathrm{N}=\text { trust and relational norms, } \mathrm{C}=\text { contract, } \mathrm{IC}= \\
\text { informal control, } \mathrm{FC}=\text { formal control }\end{array}$ & Pattern \\
\hline $\begin{array}{l}\text { HIGHPO } \\
\mathrm{T} \\
\text { Interactio } \\
\mathrm{n} 1\end{array}$ & & $\begin{array}{l}\text { - C: Contract prescribes configuration sessions } \\
\text { - FC: When configuration sessions take place SF and } \\
\text { BANK employees elicit and document requirements } \\
\text { for superior's view in configuration workbook } \\
\text { - C: Configuration workbook becomes addendum to } \\
\text { contract } \\
\text { - FC: Additional requirements used subsequently to } \\
\text { formally assess performance }\end{array}$ & $\begin{array}{l}\text { Cooperati } \\
\text { on }\end{array}$ \\
\hline $\begin{array}{l}\text { HIGHPO } \\
\text { T } \\
\text { Interactio } \\
\text { n } 2\end{array}$ & & $\begin{array}{l}\text { C: Contract prescribes configuration sessions } \\
\text { - FC: When configuration sessions take place it turns } \\
\text { out that SF solution does not meet BANK's } \\
\text { expectations } \\
\text { - T/N: A new performance norm is agreed upon: } \\
\text { Contrary to the contract SF will not be obliged to } \\
\text { roll-out the solution globally in } 2010 \\
\text { - IC: New norm used to informally asses performance } \\
\text { subsequently }\end{array}$ & $\begin{array}{l}\text { Commens } \\
\text { alism }\end{array}$ \\
\hline
\end{tabular}




\begin{tabular}{|c|c|c|c|}
\hline $\begin{array}{l}\text { HIGHPO } \\
\mathrm{T} \\
\text { Interactio } \\
\mathrm{n} 3\end{array}$ & 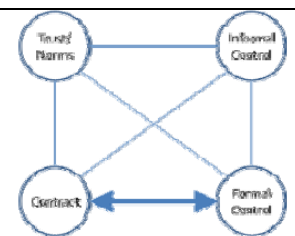 & $\begin{array}{l}\text { - C: Contract stipulates that additional rules have to be } \\
\text { mutually agreed upon } \\
\text { - } \quad \text { FC: Parties meet and further specify existing rules } \\
\text { - C: Rules with higher level of detail become an } \\
\text { addendum to the contract (OLA) }\end{array}$ & $\begin{array}{l}\text { Cooperati } \\
\text { on }\end{array}$ \\
\hline $\begin{array}{l}\text { HIGHPO } \\
\text { T } \\
\text { Interactio } \\
\text { n } 4\end{array}$ & & $\begin{array}{l}\text { - T/N: Client and vendor have an established trusted } \\
\text { relationship } \\
\text { - } \quad \text { IC: Informal knowledge exchange to specify } \\
\text { minimum safety standard for SF’s datacenter } \\
\text { - C: Minimum safety standards become addendum to } \\
\text { the contract (new OLA version) } \\
\text { - FC: Performance evaluation subsequently based on } \\
\text { minimum safety standards }\end{array}$ & $\begin{array}{l}\text { Commens } \\
\text { alism }\end{array}$ \\
\hline $\begin{array}{l}\text { HIGHPO } \\
\text { T } \\
\text { Interactio } \\
\text { n } 5\end{array}$ & & $\begin{array}{l}\text { - C: Contract prescribes policy compliance analysis } \\
\text { - FC: Policy compliance analysis is exercised and } \\
\text { reveals non-compliance } \\
\text { - IC: SF and BANK start to informally mutually } \\
\text { adjust to overcome underlying conflict of interests } \\
\text { - T/N: SF and BANK agree upon a new compromise } \\
\text { norm } \\
\text { - C: New norm gets formalized and becomes an } \\
\text { addendum to the contract } \\
\text { - FC: Performance evaluation subsequently based } \\
\text { upon the addendum }\end{array}$ & $\begin{array}{l}\text { Mutualis } \\
\mathrm{m}\end{array}$ \\
\hline $\begin{array}{l}\text { HIGHPO } \\
\mathrm{T} \\
\text { Interactio } \\
\mathrm{n} 6\end{array}$ & & $\begin{array}{l}\text { - C: Contract stipulates that additional rules have to be } \\
\text { mutually agreed upon } \\
\text { - FC: Parties meet to find out how to best configure } \\
\text { SF system for multiple languages } \\
\text { - C: New rule on multiple-language configuration } \\
\text { becomes an addendum to the contract } \\
\text { - } \quad \text { FC: New rule basis for subsequent behavior control }\end{array}$ & $\begin{array}{l}\text { Cooperati } \\
\text { on }\end{array}$ \\
\hline $\begin{array}{l}\text { HIGHPO } \\
\mathrm{T} \\
\text { Interactio } \\
\mathrm{n} 7\end{array}$ & & $\begin{array}{l}\text { - C: Contract contains right for internal audit. } \\
\text { - FC: Audit is performed and a number of issues is } \\
\text { detected. One of these issues is that BANK refrains } \\
\text { from exercising contractually stipulated KPI- } \\
\text { evaluation. } \\
\text { - C, FC: As a result, contractually-stipulated KPIs are } \\
\text { monitored subsequently. }\end{array}$ & $\begin{array}{l}\text { Cooperati } \\
\text { on }\end{array}$ \\
\hline $\begin{array}{l}\text { HIGHPO } \\
\mathrm{T} \\
\text { Revolutio } \\
\mathrm{n}\end{array}$ & $\mathrm{n} / \mathrm{a}$ & $\begin{array}{l}\text { C: New KOP that obliges SF to follow totally } \\
\text { redesigned and significantly more restrictive release } \\
\text { process } \\
\text { - C, FC: New, more strict quality assurance process is } \\
\text { introduced and followed } \\
\text { - C, FC: New deployment process is introduced and } \\
\text { followed } \\
\text { - C, FC: New, more demanding service levels are } \\
\text { introduced and followed } \\
\text { - FC: Existing meeting given more weight } \\
\text { - C, FC: New scorecard is introduced and } \\
\text { monitoredFC: Meeting staffed with senior } \\
\text { management }\end{array}$ & $\mathrm{n} / \mathrm{a}$ \\
\hline
\end{tabular}


Table 6: Case Results: HIGHPOT

\begin{tabular}{|c|c|c|c|}
\hline $\begin{array}{l}\text { Case / } \\
\text { Interacti } \\
\text { on }\end{array}$ & Illus-tration & $\begin{array}{l}\text { Description } \\
\mathrm{T} / \mathrm{N}=\text { trust and relational norms, } \mathrm{C}=\text { contract, } \mathrm{IC}= \\
\text { informal control, } \mathrm{FC}=\text { formal control }\end{array}$ & Pattern \\
\hline $\begin{array}{l}\text { CANDID } \\
\text { ATE } \\
\text { Interac- } \\
\text { tion } 1\end{array}$ & & $\begin{array}{l}\text { - C: Contract defines configuration sessions and on- } \\
\text { site workshops } \\
\text { - } \quad \text { FC: Workshops take place } \\
\text { - T/N: Within workshops trust and shared norms } \\
\text { formed } \\
\text { - } \quad \text { IC: Parties started to informally adjust in workshops } \\
\text { and web-meetings }\end{array}$ & $\begin{array}{l}\text { Commens } \\
\text { alism }\end{array}$ \\
\hline $\begin{array}{l}\text { CANDID } \\
\text { ATE } \\
\text { Interac- } \\
\text { tion } 2\end{array}$ & & $\begin{array}{l}\text { - C: Contract is unspecific concerning degree of } \\
\text { customization and stipulates to mutually agree on } \\
\text { that later on } \\
\text { - FC: Vurv and BANK meet to agree on degree of } \\
\text { standardization } \\
\text { - T/N: Vurv and BANK agree on new performance } \\
\text { norm that expresses both parties will to customize } \\
\text { the software } \\
\text { - IC: New performance norm serves as foundation for } \\
\text { subsequent informal performance assessment, while } \\
\text { (unspecific) contract remains untouched }\end{array}$ & $\begin{array}{l}\text { Commens } \\
\text { alism }\end{array}$ \\
\hline $\begin{array}{l}\text { CANDID } \\
\text { ATE } \\
\text { Interactio } \\
\text { n } 3\end{array}$ & & $\begin{array}{l}\text { - C: Contract does not specify requirements and rules } \\
\text { for implementing them } \\
\text { - T/N: Parties rely on cooperative relationship } \\
\text { - } \quad \text { IC: Cooperative relationship allows parties to } \\
\text { implement customization informally }\end{array}$ & $\begin{array}{l}\text { Commens } \\
\text { alism }\end{array}$ \\
\hline $\begin{array}{l}\text { CANDID } \\
\text { ATE } \\
\text { Interactio } \\
\text { n } 4\end{array}$ & & $\begin{array}{l}\text { - C: Contract stipulates that BANK is part of regular } \\
\text { release cycle } \\
\text { - FC: Regular releases do not work properly. Vurv and } \\
\text { BANK have formal meetings } \\
\text { - T/N: BANK and Vurv agree upon new norm } \\
\text { - IC: New norm used to informally asses performance } \\
\text { subsequently }\end{array}$ & $\begin{array}{l}\text { Commens } \\
\text { alism }\end{array}$ \\
\hline $\begin{array}{l}\text { CANDID } \\
\text { ATE } \\
\text { Revolutio } \\
n\end{array}$ & $\mathrm{n} / \mathrm{a}$ & $\begin{array}{l}\text { - FC: Instead of informal problem solving sheer } \\
\text { fulfillment of contractual obligations } \\
\text { - } \quad \text { C, FC: Contractually agreed global roll-out stopped } \\
\text { - FC: Contractually defined formal controls handled } \\
\text { more strict } \\
\text { - } \quad \text { C, FC: Introduction and exercise of new build } \\
\text { process } \\
\text { - C, FC: New KPIs as addendum to the contract and } \\
\text { basis for subsequent formal control }\end{array}$ & $\mathrm{n} / \mathrm{a}$ \\
\hline
\end{tabular}

Table 7: Case Results: CANDIDATE

\begin{tabular}{|l|l|l|l|}
\hline $\begin{array}{l}\text { Case / } \\
\text { Interacti }\end{array}$ & Illustration & $\begin{array}{l}\text { Description } \\
\mathrm{T} / \mathrm{N}=\text { trust and relational norms, } \mathrm{C}=\text { contract, } \mathrm{IC}=\end{array}$ & Pattern \\
\hline
\end{tabular}




\begin{tabular}{|c|c|c|c|}
\hline on & & informal control, FC = formal control & \\
\hline $\begin{array}{l}\text { ALUMNI } \\
\text { Interactio } \\
\text { n } 1\end{array}$ & & $\begin{array}{l}\text { - IC: Informal information exchange to gather } \\
\text { necessary requirements for software development } \\
\text { - T/N: Promises and concessions improved the level } \\
\text { of trust } \\
\text { - IC: Afterwards increased level of informal } \\
\text { information exchange }\end{array}$ & $\begin{array}{l}\text { Cooperati } \\
\text { on }\end{array}$ \\
\hline $\begin{array}{l}\text { ALUMNI } \\
\text { Interactio } \\
\text { n } 2\end{array}$ & & $\begin{array}{l}\text { - IC: Frequent informal information exchange, but } \\
\text { vendor becomes unsatisfied with it } \\
\text { - C: Management agrees on a new role to bundle } \\
\text { inquiries } \\
\text { - FC: Subsequently the information exchange is } \\
\text { performed in a more formal way }\end{array}$ & $\begin{array}{l}\text { Competiti } \\
\text { on }\end{array}$ \\
\hline $\begin{array}{l}\text { ALUMNI } \\
\text { Interactio } \\
\text { n } 3\end{array}$ & & $\begin{array}{l}\text { - IC: Established way to resolve issues informally is } \\
\text { perceived as not sufficient to manage switch to new } \\
\text { platform } \\
\text { - C: BANK pushes structure into the project (e.g., } \\
\text { communication and testing plan) } \\
\text { - FC: Coordination to switch to the new platform was } \\
\text { performed in a quite structured way }\end{array}$ & $\begin{array}{l}\text { Competiti } \\
\text { on }\end{array}$ \\
\hline $\begin{array}{l}\text { ALUMNI } \\
\text { Interactio } \\
\text { n } 4\end{array}$ & & $\begin{array}{l}\text { - FC: Agreed on procedures are followed and used to } \\
\text { identify issues or change requests } \\
\text { - T/N: Based on the trusted relationship } \\
\text { - } \quad \text { IC: These issues and requests are resolved in an } \\
\text { informal way }\end{array}$ & $\begin{array}{l}\text { Commens } \\
\text { alism }\end{array}$ \\
\hline $\begin{array}{l}\text { ALUMNI } \\
\text { Interactio } \\
\text { n } 5\end{array}$ & & $\begin{array}{l}\text { - FC: Agreed on penetration tests were performed and } \\
\text { revealed several issues } \\
\text { - } \quad \text { T/N: Based on the trusted relationship } \\
\text { - } \quad \text { IC: The issues are resolved in an informal way }\end{array}$ & $\begin{array}{l}\text { Commens } \\
\text { alism }\end{array}$ \\
\hline $\begin{array}{l}\text { ALUMNI } \\
\text { Interactio } \\
\text { n } 6\end{array}$ & & $\begin{array}{l}\text { - } \quad \text { FC: Agreed on disaster recovery tests were } \\
\text { performed and revealed several issues } \\
\text { - } \quad \text { T/N: Based on the trusted relationship } \\
\text { - } \quad \text { IC: The issues are resolved in an informal way }\end{array}$ & $\begin{array}{l}\text { Commens } \\
\text { alism }\end{array}$ \\
\hline $\begin{array}{l}\text { ALUMNI } \\
\text { Interactio } \\
\text { n } 7\end{array}$ & & $\begin{array}{l}\text { - IC: Requirements for the OLA are gathered } \\
\text { informally } \\
\text { - C: OLA is created } \\
\text { - FC: The OLA is used to manage the day-to-day } \\
\text { interaction }\end{array}$ & $\begin{array}{l}\text { Commens } \\
\text { alism }\end{array}$ \\
\hline
\end{tabular}

Table 8: Case Results: ALUMNI

\begin{tabular}{|l|l|l|l|l|l|l|}
\hline $\begin{array}{l}\text { Case / } \\
\text { Archetype }\end{array}$ & $\begin{array}{l}\text { Mutual } \\
\text { Beneficial: } \\
\text { Mutualism }\end{array}$ & $\begin{array}{l}\text { Mutual } \\
\text { Beneficial: } \\
\text { Cooperation }\end{array}$ & $\begin{array}{l}\text { Commensal } \\
\text { ism }\end{array}$ & $\begin{array}{l}\text { Competitio } \\
\mathrm{n}\end{array}$ & $\begin{array}{l}\text { Amansalis } \\
\mathrm{m}\end{array}$ & Antagonism \\
\hline HIGHPOT & $\begin{array}{l}4 \\
\text { (I5) }\end{array}$ & $\begin{array}{l}4 \\
\text { (I1, I3, I6, } \\
\text { I7) }\end{array}$ & $\begin{array}{l}2 \\
\text { (I2, I4) }\end{array}$ & 0 & 0 & 0 \\
\hline PAYSLIP & 0 & 5 & 3 & 0 & 0 & 0 \\
\hline
\end{tabular}




\begin{tabular}{|l|l|l|l|l|l|l|}
\hline & & $\begin{array}{l}\text { (I2, I3, I6, } \\
\text { I7, I8) }\end{array}$ & (I1, I4, I5) & & & \\
\hline $\begin{array}{l}\text { CANDIDA } \\
\text { TE }\end{array}$ & 0 & 0 & $\begin{array}{l}4 \\
\text { (I1, I2, I3, } \\
\text { I4) }\end{array}$ & 0 & 0 & 0 \\
\hline ALUMNI & 0 & $\begin{array}{l}4 \\
\text { (I4, I5, I6, } \\
\text { I7) }\end{array}$ & $\begin{array}{l}2 \\
\text { (I2, I3) }\end{array}$ & 0 & 0 \\
\hline
\end{tabular}

Table 9: Interaction Patterns per Case (Reference to Interaction Ix) 